\title{
Performance of sweet potato genotypes in Brazilian regions
}

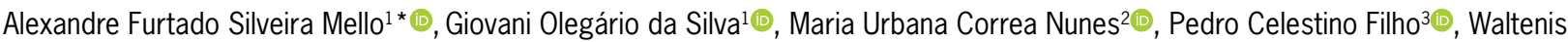 \\ Braga Silva ${ }^{4}$, Antonio Willians Moita ${ }^{1}$, José Luiz Viana de Carvalho ${ }^{5}$, Marilia Regini Nuti ${ }^{5}$
}

${ }^{1}$ Embrapa Hortalicas, BR-060, km 09, C.P. 218 - 70351 -

970 - Brasília, DF - Brasil.

2Embrapa Tabuleiros Costeiros, Av. Beira Mar, 3250 49025-040 - Aracaju, SE - Brasil.

${ }^{3}$ Embrapa Amazônia Oriental, Tv. Dr. Eneas Pinheiro, s/n. 66095-903 - Belém, PA - Brasil.

${ }^{4}$ Emdagro - Empresa de Desenvolvimento Agropecuário de Sergipe/Unidade local de Itabaiana, R. Sebastião de Oliveira, 015 - 49500-000 - Itabaiana, SE - Brasil.

${ }^{5}$ Embrapa Agroindústrias de Alimentos, Av. das Américas, 29501 - 23020-470 - Rio de Janeiro, RJ - Brasil.

*Corresponding author <alexandre.mello@embrapa.br>

Edited by: Leonardo Oliveira Medici

Received March 24, 2021

Accepted July 12, 2021
ABSTRACT: The average yield of sweet potato (Ipomoea batatas (L.) Lam.) in Brazil is below the crop potential, and appropriate cultural practices and more productive cultivars are needed to improve crop yield. The Beauregard sweet potato cultivar, originally from the United States, has shown high productive potential. This study evaluated the performance of features of agronomic importance of the Beauregard cultivar in comparison to local cultivars and eight sweet-potato clones in Brazilian regions. For that purpose, two sets of experiments were carried out. The first set evaluated eight sweet potato clones and cultivars Beauregard, Olho Roxo and Ourinhos in Brasília-DF and Itabaiana-SE using as criteria two foliage and six root traits. In the second set, two sweet potato clones (9 and 75), and Beauregard, Brazlândia Branca and Canadense cultivars were evaluated in Piacatú-SP, Brasilia-DF, PAD-DF, Canoinhas-SC and Altamira-PA, for the traits: commercial, non-commercial, and total yield. Beauregard presented little foliage production but great root yield across the different environments. Since it has low dry matter content, acceptance of this cultivar may be limited in some regions. None of the sweet potato clones showed stable yield to justify a commercial launch.

Keywords: adaptation, productivity, biofortification

\section{Introduction}

Sweet potato (Ipomoea batatas (L.) Lam.) is the fourth most cultivated vegetable in Brazil with 49,554 ha of cropped area and total production of 805,412 tons in 2019 (IBGE, 2021). The economic and social importance of sweet potato lies in its rusticity, wide climatic adaptation, and high capacity to generate energy in a short time.

Genetic variability within the species is very high, probably due to the high ploidy level (hexaploidy). In Brazil, sweet potatoes show considerable genetic diversity, which probably originates from sexual and asexual segregation as well as the introduction of plants from other locations (Vargas et al., 2018).

The average yield of Brazilian sweet potato in Brazil is roughly $14 \mathrm{t} \mathrm{ha}^{-1}$, below the crop potential that can reach above $40 \mathrm{tha}^{-1}$. With adequate cultivar management, yield levels can reach as much as $30 \mathrm{t} \mathrm{ha}^{-1}$ within four to five months of cultivation (Cecílio Filho et al., 2016). In Brazil, 32 cultivars of sweet potato have been registered to the Ministry of Agriculture, Livestock and Food Supply (MAPA, 2021); however, local and non-improved varieties prevail in the crop, which accounts for low yields (Cecílio Filho et al., 2016; Vargas et al., 2018). Therefore, correct crop management, fertilization and other cultural treatments as well as the use of more productive cultivars are required to improve crop yield. The performance of sweet potato cultivars and clones regarding traits of root yield may also vary according to the environment, because these traits are related to quantitative inheritance and have a strong environmental influence (Afolabi et al., 2019).

The cultivar Beauregard sweet potato is indigenous to the United States, where it was launched in 1987
(Rolston et al., 1987). In 2010, it was registered in Brazil by Brazilian Agricultural Research Corporation (Embrapa) as a cultivar that was tested and found appropriate for some Brazilian cropping conditions, including biofortification programs. The Beauregard cultivar has a pinkish root peel, elliptical tubers, intense orange flesh due to the presence of carotenoids, showing high yield potential and early production (Cecílio Filho et al., 2016; Nwosisi et al., 2017; Schultheis et al., 1999). Therefore, this study assessed the performance of the Beauregard cultivar in Brazilian regions in comparison to local cultivars and we also investigated the yield potential of new sweet potato clones.

\section{Materials and Methods}

Two sets of experiments were performed (see Table 1 for site characteristics). For all genotypes in both experiments, eight-nod cuttings were used and three of which are subterranean nodes. No climatic abnormalities, such as droughts, hail, frosts, or significant pest attacks, were detected in any of the locations (see Table 2 for weather conditions). Except for the experiments carried out in the state of Sergipe (SE), where the cropping system was organic, the remaining experiments were conducted with a pre-planting fertilization of $\mathrm{P}_{2} \mathrm{O}_{5}\left(196.8 \mathrm{~kg} \mathrm{ha}^{-1}\right), \mathrm{Ca}(76.8$ $\mathrm{kg} \mathrm{ha}^{-1}$ ) and $\mathrm{K}_{2} \mathrm{O}\left(58 \mathrm{~kg} \mathrm{ha}^{-1}\right)$ using triple superphosphate and $\mathrm{KCl}$. Weed control was performed 30 days after planting followed by the application of $30 \mathrm{~kg} \mathrm{ha}^{-1}$ of $\mathrm{N}$ as calcium nitrate. In Sergipe, the same nitrogen amount was used in the form of castor-bean cake.

For the first set of experiments, eight sweet potato clones $(6,8,9,33,50,66,75$ and 79) imported from the International Potato Center (CIP) were compared 
Table 1 - Soil, site location coordinates, planting, harvesting dates and site altitudes.

\begin{tabular}{|c|c|c|c|c|c|c|}
\hline \multicolumn{7}{|c|}{ First set of experiments } \\
\hline Site location & Soil* & Planting & Harvesting & \multicolumn{2}{|c|}{ Coordinates } & Altitude (m) \\
\hline BSB1 & Cambisol & 30 Mar 2015 & 04 Aug 2015 & $15^{\circ} 56^{\prime} 3.19^{\prime \prime} \mathrm{S}$ & $48^{\circ} 8^{\prime} 12.00^{\prime \prime} \mathrm{W}$ & 990 \\
\hline SE1 & Leptosol & 09 Apr 2015 & 18 Aug 2015 & $10^{\circ} 40.515^{\prime \prime S}$ & $37^{\circ} 21.917^{\prime \prime} \mathrm{W}$ & 159 \\
\hline BSB2 & Cambisol & 03 Dec 2015 & 13 Apr 2016 & $15^{\circ} 56^{\prime} 3.19^{\prime \prime} \mathrm{S}$ & $48^{\circ} 8^{\prime} 12.00^{\prime \prime} \mathrm{W}$ & 990 \\
\hline SE2 & Leptosol & 27 Nov 2015 & 29 Mar 2016 & $10^{\circ} 40.515^{\prime \prime} \mathrm{S}$ & $37^{\circ} 21.917^{\prime \prime} \mathrm{W}$ & 159 \\
\hline \multicolumn{7}{|c|}{ Second set of experiments } \\
\hline BSB3 & Cambisol & 25 Nov 2016 & 27 Apr 2017 & $15^{\circ} 56^{\prime} 3.19^{\prime \prime} \mathrm{S}$ & $48^{\circ} 8^{\prime} 12.00^{\prime \prime} \mathrm{W}$ & 990 \\
\hline РCT & Lixisol & 15 Oct 2016 & 06 Mar 2017 & $21^{\circ} 34^{\prime} 36.67^{\prime \prime} \mathrm{S}$ & $50^{\circ} 35^{\prime} 13.41^{\prime \prime} \mathrm{W}$ & 432 \\
\hline PAD & Plinthosol & 01 Dec 2016 & 02 May 2017 & $16^{\circ} 00^{\prime} 29^{\prime \prime} \mathrm{S}$ & $47^{\circ} 22^{\prime} 46^{\prime \prime} \mathrm{W}$ & 866 \\
\hline CAN & Gleysol & 01 Dec 2016 & 24 Apr 2017 & $26^{\circ} 11^{\prime} 23^{\prime \prime} \mathrm{S}$ & $50^{\circ} 21^{\prime} 52^{\prime \prime} \mathrm{W}$ & 795 \\
\hline ALT & Ferralsol & 10 May 2017 & 13 Sept 2017 & $52^{\circ} 39^{\prime} 35.73^{\prime \prime} \mathrm{S}$ & $3^{\circ} 26^{\prime} 98.10^{\prime \prime} \mathrm{W}$ & 90 \\
\hline
\end{tabular}

${ }^{*} \mathrm{BSB}=$ Brasilia-DF; SE = Itabaiana-SE; PCT = Piacatú-SP; PAD = PADF-DF, CAN = Canoinhas-SC; ALT = Altamira-PA* (Santos et al., 2018).

Table 2 - Climate conditions at the different site locations.

\begin{tabular}{|c|c|c|c|c|c|}
\hline \multicolumn{6}{|c|}{ First set of experiments } \\
\hline $\begin{array}{l}\text { Site } \\
\text { location* }\end{array}$ & $\begin{array}{c}\text { Average } \\
\text { air } \\
\text { temperature }\end{array}$ & $\begin{array}{l}\text { Maximum } \\
\text { air } \\
\text { temperature }\end{array}$ & $\begin{array}{l}\text { Minimum } \\
\text { air } \\
\text { temperature }\end{array}$ & $\begin{array}{l}\text { Average } \\
\text { relative } \\
\text { humidity }\end{array}$ & Precipitation \\
\hline & - & $-{ }^{\circ} \mathrm{C}-$ & - & $\%$ & $\mathrm{~mm}$ \\
\hline BSB1 & 20.7 & 21.5 & 19.9 & 68.9 & 337.4 \\
\hline SE $1^{A}$ & 23.5 & 24.1 & 23 & 83.7 & 262 \\
\hline BSB2 & 23.1 & 23.8 & 22.3 & 73.1 & 776 \\
\hline SE2 ${ }^{A}$ & 27 & 27.8 & 26.3 & 69.1 & 50 \\
\hline \multicolumn{6}{|c|}{ Second set of experiments } \\
\hline BSB3 & 22.5 & 23.3 & 21.8 & 72.9 & 760 \\
\hline $\mathrm{PCT}^{\mathrm{B}}$ & 25.5 & 26.2 & 24.7 & 74.4 & 860 \\
\hline PAD & 22.5 & 23.1 & 21.7 & 76.8 & 923 \\
\hline CANC & 19.3 & 32.1 & 8.7 & 83.7 & 437 \\
\hline ALT & 29.8 & 33.1 & 24 & 72.9 & 265 \\
\hline
\end{tabular}

${ }^{*} \mathrm{BSB}=$ Brasília-DF; SE = Itabaiana-SE; $\mathrm{PCT}=$ Piacatú-SP; PAD = PADF-DF, $\mathrm{CAN}=$ Canoinhas-SC; ALT = Altamira-PA; ${ }^{A}$ Data obtained from the nearest station in Carira, SE; ${ }^{B}$ Data obtained from the nearest station in Tupã, SP; ${ }^{c}$ Weather station was installed in 2017, data presented was the average from 2017-2021

to cultivars Beauregard, Olho Roxo, and Ourinhos. Cultivars Olho Roxo, and Ourinhos are cultivated by local growers in Sergipe. Table 1 shows the planting dates. The experimental design of both experiments was a fourreplicate randomized block design. The experimental plots included ten-plant rows, spaced $80 \mathrm{~cm}$ between rows and $30 \mathrm{~cm}$ between plants $\left(2.40 \mathrm{~m}^{2}\right)$, with an external border row in each block, which was not evaluated.

Since plant foliage can be used as animal forage, plants from each plot were harvested and the fresh mass weight (FFW) and the shoot dry matter (FDM) of the plants were evaluated. Dry matter (DM) was determined by drying $0.5 \mathrm{~kg}$ of canopy samples in an oven at 70 ${ }^{\circ} \mathrm{C}$ for $48 \mathrm{~h}$. Root evaluations included the number of commercial roots (NCR), commercial yield (CY), the mean commercial root mass for the ratio between $\mathrm{CY}$ and NCR (AVCR), noncommercial yield (NCY), length (COMP), and average diameter (DIAM) of commercial roots. Roots up to $10 \mathrm{~cm}$ long and $5 \mathrm{~cm}$ in diameter with no tortuosity, pest damage, or cracking were considered commercial. FFW, FDM, CY, NCY data were expressed as $\mathrm{t} \mathrm{ha} \mathrm{h}^{-1}$, NCR was also transformed to $\mathrm{tha}^{-1}$, and AVCR was expressed in grams to facilitate comparison with the literature.

For the second set of experiments, two sweet potato clones were selected (9 and 75), cultivars Beauregard, Brazlândia Branca, and Canadense. Cultivars Brazlândia Branca and Canadense are largely cultivated by Brazilian growers in the different regions. Cultivar Brazlândia Branca and Canadense were not evaluated in the Canoinhas, state of Santa Catarina (SC) experiment and cultivar Canadense was not evaluated in the Brasília-DF experiment. Table 1 shows information on the planting procedures. The experimental design was the same of the first set of experiments.

Plants from each plot were harvested and evaluated for the following root traits: commercial yield $(\mathrm{CY})$; noncommercial yield (NCY); and total root mass (TRM). Roots up to $10 \mathrm{~cm}$ in length and $5 \mathrm{~cm}$ in diameter without tortuosity, pest damage, or cracking were considered commercial. Data were expressed as $\mathrm{t} \mathrm{ha}^{-1}$ to facilitate comparison with the literature.

Data from each set of experiments were submitted to the individual and combined analysis of variance with the Proc GLM procedure in SAS (Statistical Analysis System, version 9.1). Adaptability and stability for commercial root yield $t h^{-1}(\mathrm{CY})$ for the common genotypes in all environments were evaluated with the AMMI model (Zobel et al., 1988) using the statistical software SAS (Statistical Analysis System, version 9.1). The means cluster by Scott-Knott at $5 \%$ and simple correlation analysis were carried out using the statistical software GENES.

\section{Results and Discussion}

Significant differences between genotypes were detected through the combined analysis of variance and in the interaction between cultivars and cultivation sites for all traits evaluated on the first set of experiments (Table 3). The genotypes were different from each other for the evaluated characteristics and their performances vary 
Table 3 - Summary of the combined variance analysis for root characters and aerial parts evaluated in 11 sweet potato genotypes in Brasilia and Sergipe in the crops of 2015 and 2016.

\begin{tabular}{|c|c|c|c|c|c|}
\hline \multirow{2}{*}{ Variation } & \multirow{2}{*}{$\mathrm{DL}$} & \multicolumn{4}{|c|}{ Square Means } \\
\hline & & NCR & $\mathrm{CY}$ & AVCR & $\mathrm{NCY}$ \\
\hline Genotype (G) & 10 & $10348.39^{*}$ & $426.74^{*}$ & $1335.02^{*}$ & $29.94 *$ \\
\hline Site Location (SL) & 1 & $22376.55^{*}$ & $3235.59^{*}$ & $61738.15^{*}$ & $9.46^{*}$ \\
\hline Cropping Season (CS) & 1 & $612431.82^{*}$ & $42064.19^{*}$ & $29970.63^{*}$ & $606.81^{*}$ \\
\hline $\mathrm{G} \times \mathrm{SL}$ & 10 & $199268.57^{*}$ & $17279.47^{*}$ & $15175.78^{*}$ & $41.83^{*}$ \\
\hline $\mathrm{G} \times \mathrm{CS}$ & 10 & $8053.37^{*}$ & $888.27^{*}$ & 9727.51 & 15.43 \\
\hline $\mathrm{SL} \times \mathrm{CS}$ & 1 & $5222.26^{*}$ & $815.82^{*}$ & 2399.71 & 5.69 \\
\hline $\mathrm{G} \times \mathrm{SL} \times \mathrm{CS}$ & 10 & 60313.73 & $3828.85^{*}$ & 2300.44 & $1.57^{*}$ \\
\hline Residue & 129 & 1969.21 & 105.30 & 1853.21 & 3.54 \\
\hline Means & - & 183.83 & 43.47 & 234.17 & 5.87 \\
\hline \multirow[t]{2}{*}{ CV (\%) } & - & 24.14 & 23.60 & 18.38 & 32.05 \\
\hline & & COMP & DIAM & FFW & FDM \\
\hline Genotype (G) & 10 & $3.34^{*}$ & $0.16^{*}$ & $1170.46^{*}$ & $80.73^{*}$ \\
\hline Site Location (SL) & 1 & $52.23^{*}$ & $13.04^{*}$ & $11479.31^{*}$ & $1021.76^{*}$ \\
\hline Cropping Season (CS) & 1 & $387.05^{*}$ & 2.51 & $411223.55^{\star}$ & $34113.74^{*}$ \\
\hline $\mathrm{G} \times \mathrm{SL}$ & 10 & $67.51^{*}$ & $0.28^{*}$ & $1433.15^{*}$ & $11835.72^{*}$ \\
\hline $\mathrm{G} \times \mathrm{CS}$ & 10 & $15.53^{*}$ & 1.01 & $7236.26^{*}$ & $797.21^{*}$ \\
\hline $\mathrm{SL} \times \mathrm{CS}$ & 1 & $5.01^{*}$ & $0.33^{*}$ & $2167.30^{*}$ & $484.28^{*}$ \\
\hline $\mathrm{G} \times \mathrm{SL} \times \mathrm{CS}$ & 10 & $30.28^{*}$ & 1.64 & $10285.12^{*}$ & $11503.50^{*}$ \\
\hline Residue & 129 & 1.48 & 0.32 & 343.78 & 88.59 \\
\hline Mean & - & 16.12 & 5.10 & 82.35 & 20.75 \\
\hline CV (\%) & - & 7.55 & 11.10 & 22.51 & 45.35 \\
\hline
\end{tabular}

according to crop location (Brasília, DF and Itabaiana, $\mathrm{SE})$. The site effects can also be attested by the analysis of variance. Although the growing season effect was significant for almost all the characteristics, except for DIAM, there were different responses of genotypes due to the growing season to number of NCR and CY, COMP and FFW and FDM. For most responses, except DIAM, siteto-growing season interaction was significant, confirming different responses of site effects in the evaluations of twogrowing seasons (Table 3). Thus, for traits that presented different responses according to the growing season and site location, comparisons were made separately per growing season and site, while for the others, a separate discussion was done per site, but using the average of the two seasons.

The coefficients of environmental variation (CV) obtained in the combined analyses of variance had low values, and as expected for sweet potatoes between the traits evaluated, NCY (32.05\%) and FDM (45.35\%) presented the higher $\mathrm{CV}$, thereby indicating lower precision and lower reliability in the estimates of these two traits. Dumbuya et al. (2016) also reported that NCY has high environmental influence. The authors detected CV of $64.01 \%$ for this trait. The same authors detected CV of $14.70 \%$ for a number of commercial roots and $23.90 \%$ for CY. Melo et al. (2020) also observed higher experimental accuracy for DIAM and root length (COMP) with values of 11.89 and $13.30 \%$, while in this study, these values were between 11.10 and $7.55 \%$, respectively (Table 3).
The average CY for this first set of experiments was $23.60 \mathrm{t} \mathrm{ha}^{-1}$ (Table 3), similar to those obtained in other studies with improved materials (Andrade Junior, 2009; Melo et al., 2020) and well above the average Brazilian yield of $14.07 \mathrm{t} \mathrm{ha}^{-1}$ (IBGE, 2021).

In the Brasillia-DF experiment, clone 66 was the most productive genotype in both years with an average over $100 \mathrm{t} \mathrm{ha}^{-1}$. Cultivar Beauregard had high yield of commercial roots, the second most productive genotype (Table 4). All genotypes presented greater yield in Brasília in 2015 than in 2016 (Table 4). Since, fertilization and soil conditions were very similar, rainfall and higher average temperature in 2016 possibly enabled greater yield in that year (Tables 2 and 4). In Itabaiana-SE, clone 66 and cultivar Beauregard were the most productive in both years (Table 4).

Studies on cultivar Beauregard conducted in North Carolina and Tennessee (the United States) showed total yields ranging from 25.5 to $34.9 \mathrm{t} \mathrm{ha}^{-1}$ in the former and $40 \mathrm{t} \mathrm{ha}^{-1}$ in the latter obtained at 132 and 126 days after planting, respectively (Nwosisi et al., 2017; Schultheis et al., 1999). Similar results were found in Brazil where commercial root yield ranged from 28.18 to $35.68 \mathrm{t} \mathrm{ha}^{-1}$ for the Beauregard cultivar (Melo et al., 2020). These values were lower than the average $\left(61.4 \mathrm{t} \mathrm{ha}^{-1}\right)$ of the four present studies (Table 4), showing that yield potential for Beauregard in some Brazilian regions can be even greater than that described in the literature. 
Table 4 - Means cluster by Scott-Knott for root and shoot variables, which showed site-to-growing season genotype interaction, evaluated in 11 sweet potato genotypes in Brasilia and Sergipe in the years of 2015 and 2016.

\begin{tabular}{|c|c|c|c|c|c|}
\hline \multicolumn{6}{|c|}{ Brasilia, 2015} \\
\hline Genotype & NCR & $\mathrm{CY}$ & COMP & FFW & FDM \\
\hline 6 & $219.5 \mathrm{a}$ & $50.6 \mathrm{c}$ & $17.7 \mathrm{~b}$ & $150.1 \mathrm{~b}$ & $23.0 \mathrm{~b}$ \\
\hline 8 & $185.7 \mathrm{a}$ & $31.9 c$ & $17.2 \mathrm{~b}$ & $104.9 \mathrm{c}$ & $16.0 \mathrm{c}$ \\
\hline 9 & $216.0 \mathrm{a}$ & $61.8 b$ & $17.2 \mathrm{~b}$ & $197.2 \mathrm{a}$ & $30.2 a$ \\
\hline 33 & 76.2 b & $21.4 \mathrm{c}$ & $17.2 \mathrm{~b}$ & $153.9 \mathrm{~b}$ & $23.6 b$ \\
\hline 50 & $280.2 \mathrm{a}$ & $51.0 \mathrm{~b}$ & $16.0 \mathrm{~b}$ & $125.6 \mathrm{c}$ & $19.2 \mathrm{c}$ \\
\hline 66 & $214.0 \mathrm{a}$ & $76.9 a$ & $13.2 \mathrm{c}$ & $109.4 \mathrm{c}$ & $16.7 \mathrm{c}$ \\
\hline 75 & $232.7 \mathrm{a}$ & $40.4 \mathrm{c}$ & $13.2 \mathrm{c}$ & $95.7 \mathrm{c}$ & $14.6 \mathrm{c}$ \\
\hline 79 & 200.7 a & $27.2 \mathrm{c}$ & $16.5 b$ & $86.9 c$ & $13.3 \mathrm{c}$ \\
\hline Beauregard & 167.7 a & $51.9 b$ & $14.5 \mathrm{c}$ & $91.2 \mathrm{c}$ & $13.9 c$ \\
\hline Olho Roxo & $121.5 b$ & $26.0 \mathrm{c}$ & $18.7 \mathrm{a}$ & $99.0 \mathrm{c}$ & $15.2 \mathrm{c}$ \\
\hline Ourinhos & 182.7 a & $48.7 \mathrm{~b}$ & $20.5 \mathrm{a}$ & $108.3 c$ & $16.6 \mathrm{c}$ \\
\hline \multicolumn{6}{|c|}{ Brasília, 2016} \\
\hline Genotype & NCR & $\mathrm{CY}$ & COMP & FFW & FDM \\
\hline 6 & $250.0 c$ & $60.0 \mathrm{~d}$ & $19.0 \mathrm{~b}$ & $177.8 \mathrm{~b}$ & $54.7 \mathrm{c}$ \\
\hline 8 & $243.8 c$ & $40.1 \mathrm{~d}$ & $20.5 b$ & $78.4 \mathrm{~d}$ & $25.9 c$ \\
\hline 9 & $297.3 \mathrm{c}$ & $78.2 \mathrm{c}$ & $15.2 \mathrm{c}$ & $299.5 \mathrm{a}$ & $110.3 a$ \\
\hline 33 & $280.2 \mathrm{c}$ & $104.5 b$ & $19.5 b$ & $132.5 \mathrm{c}$ & $65.3 b$ \\
\hline 50 & $437.8 \mathrm{a}$ & $75.3 c$ & $19.7 \mathrm{~b}$ & $132.0 \mathrm{c}$ & $34.1 \mathrm{c}$ \\
\hline 66 & $352.0 \mathrm{~b}$ & $130.5 \mathrm{a}$ & $14.0 \mathrm{c}$ & $104.3 d$ & $43.9 c$ \\
\hline 75 & $331.0 \mathrm{~b}$ & $66.6 \mathrm{c}$ & $15.0 \mathrm{c}$ & $90.8 d$ & $39.1 \mathrm{c}$ \\
\hline 79 & $326.3 b$ & $49.4 \mathrm{~d}$ & $20.0 \mathrm{~b}$ & $94.1 \mathrm{~d}$ & $23.5 c$ \\
\hline Beauregard & $282.8 \mathrm{c}$ & $97.8 \mathrm{~b}$ & $16.0 \mathrm{c}$ & $80.6 \mathrm{~d}$ & $29.1 \mathrm{C}$ \\
\hline Olho Roxo & $198.4 \mathrm{c}$ & $48.8 \mathrm{~d}$ & $23.2 \mathrm{a}$ & $182.9 \mathrm{~b}$ & $65.4 \mathrm{~b}$ \\
\hline Ourinhos & $245.0 \mathrm{c}$ & $57.2 \mathrm{~d}$ & $22.7 \mathrm{a}$ & $180.0 \mathrm{~b}$ & $69.2 b$ \\
\hline \multicolumn{6}{|c|}{ Sergipe, 2015} \\
\hline Genotype & NCR & $\mathrm{CY}$ & COMP & FFW & FDM \\
\hline 6 & 120.7 a & $26.9 b$ & $14.7 \mathrm{a}$ & $31.3 c$ & $5.4 \mathrm{c}$ \\
\hline 8 & $85.7 \mathrm{~b}$ & $17.3 \mathrm{c}$ & $16.0 \mathrm{a}$ & $33.8 \mathrm{c}$ & $5.8 \mathrm{c}$ \\
\hline 9 & $63.7 c$ & $13.5 \mathrm{c}$ & $13.0 \mathrm{~b}$ & $56.0 \mathrm{a}$ & $8.1 \mathrm{a}$ \\
\hline 33 & $50.5 c$ & $13.4 \mathrm{c}$ & $15.7 \mathrm{a}$ & $56.3 \mathrm{a}$ & $9.7 \mathrm{a}$ \\
\hline 50 & 146.5 a & $23.1 b$ & $13.5 b$ & $36.8 \mathrm{c}$ & $7.2 \mathrm{c}$ \\
\hline 66 & $152.0 \mathrm{a}$ & $40.3 \mathrm{a}$ & $11.5 \mathrm{~b}$ & $52.1 \mathrm{a}$ & $9.1 \mathrm{a}$ \\
\hline 75 & $121.7 \mathrm{a}$ & $21.9 b$ & $13.5 b$ & $42.0 \mathrm{~b}$ & $7.1 \mathrm{~b}$ \\
\hline 79 & $98.2 \mathrm{~b}$ & $17.5 \mathrm{c}$ & $15.2 \mathrm{a}$ & $19.8 d$ & $3.2 \mathrm{~d}$ \\
\hline Beauregard & 144.7 a & $44.2 \mathrm{a}$ & $14.0 \mathrm{~b}$ & $18.2 d$ & $3.9 d$ \\
\hline Olho Roxo & $105.2 \mathrm{a}$ & $14.0 \mathrm{c}$ & $16.0 \mathrm{a}$ & $42.0 \mathrm{~b}$ & $6.4 b$ \\
\hline Ourinhos & $117.5 \mathrm{a}$ & $18.1 \mathrm{C}$ & $15.5 \mathrm{a}$ & $38.4 \mathrm{c}$ & $7.8 \mathrm{c}$ \\
\hline \multicolumn{6}{|c|}{ Sergipe, 2016} \\
\hline Genotype & NCR & $\mathrm{CY}$ & COMP & FFW & FDM \\
\hline 6 & $145.0 \mathrm{a}$ & $37.3 b$ & $14.7 b$ & $22.9 \mathrm{c}$ & $5.8 \mathrm{c}$ \\
\hline 8 & $151.5 \mathrm{a}$ & $35.3 b$ & $17.0 \mathrm{a}$ & $29.6 b$ & $5.8 \mathrm{c}$ \\
\hline 9 & $88.2 \mathrm{~b}$ & $19.6 \mathrm{c}$ & $12.2 \mathrm{c}$ & $38.0 \mathrm{a}$ & $7.1 \mathrm{c}$ \\
\hline 33 & $146.2 \mathrm{a}$ & $40.3 b$ & $16.5 \mathrm{a}$ & $30.58 \mathrm{~b}$ & $5.8 \mathrm{c}$ \\
\hline 50 & $159.5 \mathrm{a}$ & $25.2 \mathrm{c}$ & $15.7 \mathrm{a}$ & $29.8 b$ & $8.2 b$ \\
\hline 66 & 146.7 a & $53.4 \mathrm{a}$ & $12.7 \mathrm{c}$ & $31.1 \mathrm{~b}$ & $6.7 c$ \\
\hline 75 & $182.5 \mathrm{a}$ & $38.3 b$ & $13.7 b$ & $26.9 b$ & $6.9 c$ \\
\hline 79 & $156.0 \mathrm{a}$ & $33.4 b$ & $14.5 b$ & $20.6 \mathrm{c}$ & $5.5 c$ \\
\hline Beauregard & $174.0 \mathrm{a}$ & $51.5 \mathrm{a}$ & $16.5 \mathrm{a}$ & $18.7 \mathrm{c}$ & $3.6 \mathrm{c}$ \\
\hline Olho Roxo & $78.0 \mathrm{~b}$ & $10.9 d$ & $15.0 \mathrm{~b}$ & $42.8 \mathrm{a}$ & $11.6 \mathrm{a}$ \\
\hline Ourinhos & $112.0 \mathrm{~b}$ & $20.5 c$ & $14.5 b$ & $30.4 \mathrm{~b}$ & $9.5 b$ \\
\hline
\end{tabular}

In both sites, clone 66 and cultivar Beauregard showed the largest average mass of commercial roots, along with clone 33 in the Brasília-DF experiments (Table 5). Clone 66 showed roots with an average mass of $343.1 \mathrm{~g}$ and Beauregard, 319.2 g. Schultheis et al. (1999) also described the potential of Beauregard to produce large-mass roots with the harvest of commercial size roots under cropping conditions in the United States and 90 days after planting. These values are in accordance with the ideal size for the market, which ranges from 200 to $400 \mathrm{~g}$ (Miranda, 1989). Melo et al. (2020) found a commercial root weight average of $321.5 \mathrm{~g}$ for Beauregard in Brasilia-DF, Brazil. As cultural and climatic conditions in Brazil vary greatly across its territory, the ideal harvest time for sweet potato and therefore the ideal root size may also vary according to preferences of consumers in local markets (Melo et al., 2020).

Genotypes with high CY in the sites and years also show roots with the largest average diameter (DIAM) (Table 3), with a correlation of $92 \%$ (Table 6). This also agrees with a previous study that found a correlation of 0.56 between these traits (Afuape et al., 2011).

The genotypes had an average COMP of 16.12 cm. In Brasilia, cultivars Ourinhos and Olho Roxo presented the largest roots, while in Sergipe, different

Table 5 - Means cluster by Scott-Knott for root and shoot variables, which did not show growing season-genotype interaction, evaluated in 11 sweet potato genotypes in Brasilia and Sergipe in the years of 2015 and 2016.

\begin{tabular}{|c|c|c|c|}
\hline \multicolumn{4}{|c|}{ Brasilia } \\
\hline Genotype & AVCR & $\mathrm{NCY}$ & DIAM \\
\hline 6 & $233.5 c$ & $3.7 \mathrm{a}$ & $4.5 d$ \\
\hline 8 & $175.7 \mathrm{~d}$ & $3.7 \mathrm{a}$ & $4.0 \mathrm{~d}$ \\
\hline 9 & $279.0 \mathrm{~b}$ & $3.5 \mathrm{a}$ & $5.5 c$ \\
\hline 33 & $330.2 \mathrm{a}$ & $5.0 \mathrm{a}$ & $6.0 \mathrm{~b}$ \\
\hline 50 & $188.0 \mathrm{~d}$ & $4.0 \mathrm{a}$ & $4.5 d$ \\
\hline 66 & $368.7 \mathrm{a}$ & $2.7 \mathrm{a}$ & $7.0 \mathrm{a}$ \\
\hline 75 & $192.0 \mathrm{~d}$ & $4.0 \mathrm{a}$ & $5.2 c$ \\
\hline 79 & $141.2 \mathrm{~d}$ & $6.0 \mathrm{a}$ & $3.7 d$ \\
\hline Beauregard & $333.5 \mathrm{a}$ & $5.2 a$ & $6.0 \mathrm{~b}$ \\
\hline Olho Roxo & $228.7 \mathrm{c}$ & $3.7 \mathrm{a}$ & $4.0 \mathrm{~d}$ \\
\hline Ourinhos & $248.5 c$ & $2.2 \mathrm{a}$ & $4.2 \mathrm{~d}$ \\
\hline \multicolumn{4}{|c|}{ Sergipe } \\
\hline Genotype & AVCR & $\mathrm{NCY}$ & DIAM \\
\hline 6 & $247.0 \mathrm{~b}$ & $7.2 \mathrm{~b}$ & $5.2 b$ \\
\hline 8 & 220.2 c & $9.5 a$ & $5.0 \mathrm{~b}$ \\
\hline 9 & $214.5 \mathrm{c}$ & $7.7 \mathrm{~b}$ & $5.5 b$ \\
\hline 33 & $277.0 \mathrm{~b}$ & $6.7 b$ & $5.5 b$ \\
\hline 50 & $156.5 d$ & $9.2 \mathrm{a}$ & $4.5 c$ \\
\hline 66 & $317.5 \mathrm{a}$ & $6.7 b$ & $6.7 \mathrm{a}$ \\
\hline 75 & 194.7 c & $9.5 \mathrm{a}$ & $5.2 \mathrm{~b}$ \\
\hline 79 & 196.7 c & $7.2 \mathrm{~b}$ & $4.7 c$ \\
\hline Beauregard & $305.0 \mathrm{a}$ & $4.7 \mathrm{~b}$ & $6.2 \mathrm{a}$ \\
\hline Olho Roxo & $135.2 \mathrm{~d}$ & $8.7 \mathrm{a}$ & $4.2 c$ \\
\hline Ourinhos & $168.5 \mathrm{~d}$ & $7.2 \mathrm{~b}$ & $5.0 \mathrm{~b}$ \\
\hline
\end{tabular}

${ }^{*}$ Different letters within columns represent $p<0.05$ probability by Scott-Knott test; AVCR = average mass of commercial roots (g); NCY = non-commercial yield $\mathrm{t} \mathrm{ha}^{-1}$; DIAM $=$ average diameter of commercial roots $(\mathrm{cm})$. 
genotypes showed significant values according to the year. Clones 8 and 33 showed the largest roots in both years. The average root length for Beauregard, $15.2 \mathrm{~cm}$, is similar to results of a previous study $15.1 \mathrm{~cm}$ (Melo et al., 2020). In our study, this trait was negatively correlated with CY (correlation of -0.75) (Table 6). A previous study evaluated 11 sweet potato genotypes with different shapes and did not find a significant correlation between CY and COMP; however, it found a positive and significant correlation between $\mathrm{CY}$ and DIAM (0.63) (Egbe et al., 2012). Afuape et al. (2011), in turn, found a positive correlation of 0.54 between $\mathrm{CY}$ and COMP. Therefore, this association does not seem to be a rule, but dependant on the genotypes evaluated, possibly with DIAM more important than COMP to CY. In general, consumers prefer fusiform shapes of 1/3 diameter/length (Melo et al., 2020). Thus, the best expected length is on average $15.3 \mathrm{~cm}$ for the average diameter of $5.1 \mathrm{~cm}$. This was very similar to the average root length found for Beauregard $(15.2 \mathrm{~cm})$.

Shoot production (FFW and FDM) is an important trait because shoots can also be used as animal feed, adding value to their production. However, in practice, there is no association between higher shoot production and higher root productivity, as shown by the correlation matrix (Table 6). This relationship may be reversed in cases of excess $\mathrm{N}$-rich fertilizers, as excessive shoot production is detrimental to root production (Zunfu et al., 2020). The performance results of the clones showed similarity for both traits used to measure the shoots. Since FDM showed a high CV value, we opted to focus the discussion on FFW. Clone 9 showed high FFW production in both sites and cropping years with an average of $147.70 \mathrm{t} \mathrm{ha}^{-1}$, while the average for all genotypes was $82.35 \mathrm{t} \mathrm{ha}^{-1}$. Clone 79 and cultivar Beauregard were among the genotypes with the lowest FFW in all experiments. Again, clone 66, which was one of the genotypes with the highest CY, showed variable performance regarding FFW mean groups in the different experiments (Table 4).

The results for $\mathrm{CY}$ in the different environments can be better explained by the AMMI model. The

Table 6 - Correlation among root characters and aerial parts evaluated in 11 sweet potato genotypes in Brasília and Sergipe in 2015 and 2016.

\begin{tabular}{|c|c|c|c|c|c|c|c|}
\hline & NCR & CY & AVCR & NCY & COMP & DIAM & FFW \\
\hline$\overline{\mathrm{CY}}$ & $0.45^{*}$ & & & & & & \\
\hline AVCR & -0.07 & $0.85^{*}$ & & & & & \\
\hline $\mathrm{NCY}$ & 0.12 & $-0.60^{*}$ & $-0.68^{*}$ & & & & \\
\hline COMP & $-0.57^{\star}$ & $-0.75^{*}$ & $-0.48^{*}$ & 0.16 & & & \\
\hline DIAM & 0.16 & $0.92^{*}$ & $0.94^{*}$ & $-0.56^{*}$ & $-0.72^{*}$ & & \\
\hline FFW & -0.35 & -0.11 & 0.05 & -0.24 & -0.01 & 0.06 & \\
\hline FDM & $-0.46^{*}$ & -0.09 & 0.13 & -0.32 & 0.00 & 0.13 & $0.97^{*}$ \\
\hline
\end{tabular}

$\mathrm{NCR}=$ number of commercial roots ha-3 ${ }^{-3} \mathrm{CY}=$ commercial yield $\mathrm{t} \mathrm{ha}^{-1} ; \mathrm{AVCR}$ $=$ average mass of commercial roots, $\mathrm{g} ; \mathrm{NCY}=$ non-commercial yield $\mathrm{t} \mathrm{ha}^{-1}$; COMP = average length of commercial roots $(\mathrm{cm})$; DIAM = average diameter of commercial roots (cm); FFW $=$ fresh shoot mass $t^{-1} a^{-1}$; FDM $=$ dry matter of the aerial part of the plants $\mathrm{tha}^{-1}$; ${ }^{*}$ Significant at $p<0.05$ probability by $t$-test. stability was performed from the distance from the representative points of the genotypes and environments to the zero score. Thus, the points that contribute less to the interaction represent a shorter distance, indicating greater stability. The adaptability of populations to each environment is interpreted by observing the signs of scores for genotypes and environments, because genotypes and environments with scores of the same sign interact positively (Miranda et al., 2009), indicating where the genotype should preferably be cultivated.

The AMMI analysis of the commercial yield of the different sweet potato cultivars and clones in different locations in 2015 and 2016 (Figure 1) showed that Sergipe in 2015 was the environment with the lowest CY, agreeing with the results shown in Table 4. However, CY was similar in Brasília in 2015 and Sergipe in 2016. Clone 66 was the most productive genotype, but it was not adapted to a specific environment and clone 50 was more adapted to Brasília in 2015, also agreeing with Table 4 . Clones 9, 75, 6, 8, and genotypes Beauregard and Ourinhos were the most stable, but not closely linked to a single environment. Clone 79 was not adapted to a single environment; however, its yield was larger in Brasília in 2016. Clone 33 and cultivar Olho Roxo did not perform well, similar to Sergipe in 2015, which had the lowest yield.

The only orange flesh sweet potato clone that presented a yield greater than Beauregard was clone 66 (Table 4). However, this clone was not advanced to the second set of experiments due to root peel sensitiveness during root washing. Clone 9 was pre-selected as a potential white flesh cultivar. Clone 75 was also preselected for the second set of experiments because it has a desirable shape in addition to high dry matter content (above $35 \%$ ) (data not shown). Beauregard consumers in Brazil typically complain about clone 66 as it has an average dry matter of $24 \%$ (Rolston et al., 1987).

In the second set of experiments, according to the cluster analysis of variance, all traits showed differences between the genotypes evaluated as well as the interaction between genotypes and cultivation sites (Table 7). The coefficients of variation (CV) were slightly

Table 7 - Summary of the combined variance analysis for root characters evaluated in five sweet potato genotypes in Piacatú-SP, Gama-DF, PAD-DF, Canoinhas-SC and Altamira-PA, in the 2016 and 2017 harvests.

\begin{tabular}{lcrrr}
\hline Variation & DL & \multicolumn{1}{c}{ CY } & \multicolumn{1}{c}{ NCY } & \multicolumn{1}{c}{ TRY } \\
\hline Genotype (G) & 4 & $11073.87^{*}$ & $2213.48^{*}$ & $9159.69^{*}$ \\
Site Location (SL) & 4 & $32080.79^{*}$ & $5400.33^{*}$ & $63164.59^{*}$ \\
G $\times$ SL & 13 & $6327.74^{*}$ & $1245.38^{*}$ & $4361.74^{*}$ \\
Residue & 63 & 327.12 & 69.22 & 361.02 \\
Mean & - & 51.91 & 15.83 & 67.75 \\
CV (\%) & - & 34.84 & 52.54 & 28.04 \\
\hline
\end{tabular}

$\mathrm{DL}=$ degrees of liberty; $\mathrm{CV}(\%)=$ coefficient of variation; ${ }^{*} p<0.05$ by $\mathrm{F}$ test; $\mathrm{CY}=$ commercial yield $\mathrm{t} \mathrm{ha} \mathrm{a}^{-1} ; \mathrm{NCY}=$ non-commercial yield $\mathrm{t} \mathrm{ha}^{-1} ; \mathrm{TRY}=$ total root yield $t$ ha-1. 
higher for CY $(34.84 \%)$ when compared to the first set of experiments, but still similar values reported in the literature for this trait (Melo et al., 2020). The CV was rather high for NCY $(52.54 \%)$, indicating that this trait is highly influenced by the environment (Table 5).

The average mass of commercial roots for all genotypes and sites in the second set of experiments was $51.9 \mathrm{t} \mathrm{ha}^{-1}$, higher than the first set of experiments $\left(43.47 \mathrm{t} \mathrm{ha}^{-1}\right)$. For PAD-DF and Canoinhas-SC, there were no differences between the genotypes for $\mathrm{CY}$ and TRM. However, the Beauregard cultivar was the most productive in the other sites with an average CY of $89.8 \mathrm{tha}^{-1}$ in all five sites of the second set of experiments. Clone 75 was the least productive in this set of experiments, showing a large number of roots out of commercial standards (Table 8).

Commercial yield of sweet potato genotypes evaluated in the five sites was greater in PiacatúSP, followed by Brasília. The results were consistent between the different analyses performed (Figure 2 and Table 8). Similar to the first set of experiments, Beauregard was the most productive root genotype

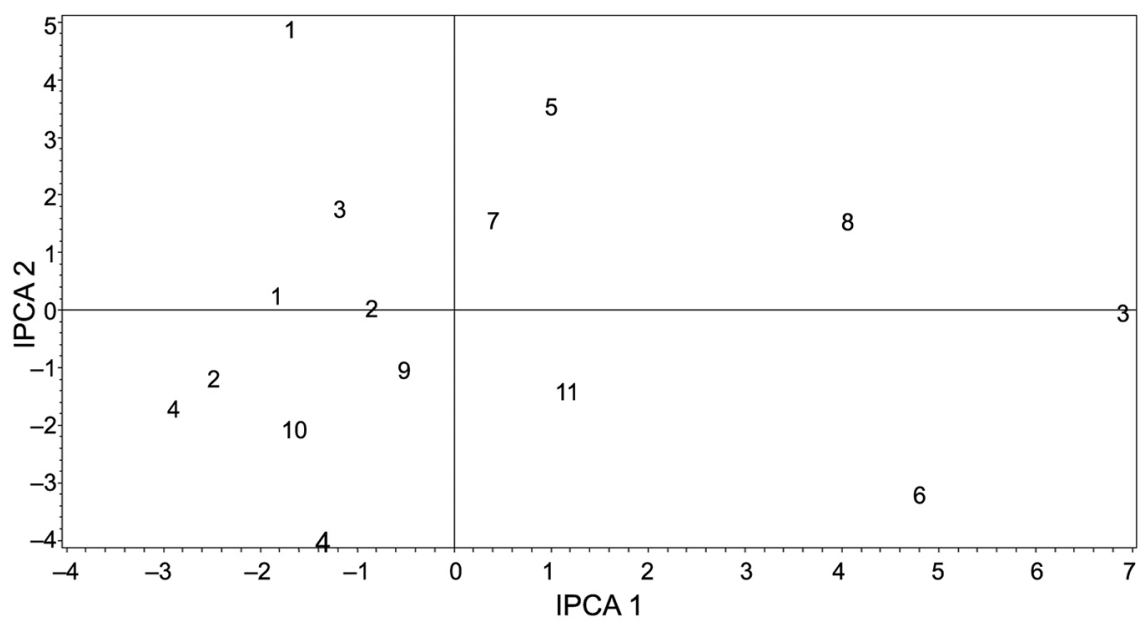

Figure 1 - Plot of the scores of the main components according to the AMMI model for the commercial yield $t \mathrm{th}^{-1}$ trait (CY) for eleven sweet potato genotypes of the first set of experiments. Evaluations were performed in Brasilia and Sergipe in two different growing seasons in each location in the years 2015 and 2016. Comments: numbers with larger font size represent the environments: $1=$ Brasilia-2015; $2=$ Sergipe-2015; 3 = Brasilia-2016; 4 = Sergipe-2016. Numbers with smaller font size represent the genotypes: $1=$ Clone 6; 2 = Clone 8; $3=$ Clone 9; 4 = Clone 33; 5 = Clone 50; 6 = Clone 66; 7 = Clone 75; 8 = Clone 79; 9 = Beauregard; $10=$ Olho Roxo; $11=$ Ourinhos. The first two IPCA explained $96.36 \%$ of the total variation.

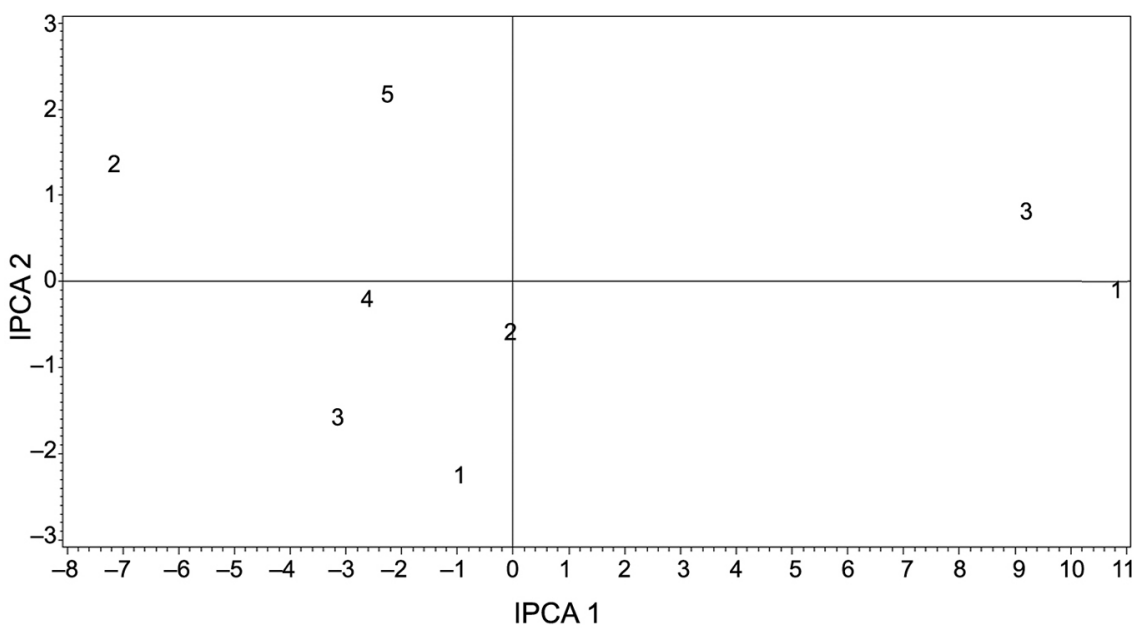

Figure 2 - Plot of the scores of the main components according to the AMMI model for the commercial yield $t$ ha ${ }^{-1}$ trait (CY) for three sweet potato genotypes in the second set of experiments. Evaluations were made in five different sites during one growing season. Genotypes are represented by numbers with a smaller font size: $1=$ Clone 9; 2 = Clone 75; 3 = Beauregard, coincident in both environments represented by numbers with a larger font size: 1 = Piacatú-SP; 2 = Brasilia-DF; 3 = PAD-DF; 4 = Canoinhas-SC and $5=$ Altamira-PA. The first two IPCA explained $100 \%$ of the total variation. 
Table 8 - Mean cluster by Scott-Knott for root characters evaluated in five sweet potato genotypes in Piacatú-SP, Brasília-DF, PAD-DF, Canoinhas-SC and Altamira-PA, in the 2016 and 2017 harvests.

\begin{tabular}{|c|c|c|c|}
\hline \multirow[b]{2}{*}{ Genotypes } & \multicolumn{3}{|c|}{ Piacatú-SP } \\
\hline & $\mathrm{CY}$ & $\mathrm{NCY}$ & TRY \\
\hline 9 & $115.0 \mathrm{~b}$ & $28.8 b$ & $143.8 b$ \\
\hline 75 & $36.4 \mathrm{c}$ & $113.3 \mathrm{a}$ & $149.8 b$ \\
\hline Beauregard & $263.2 \mathrm{a}$ & $26.5 b$ & $289.7 \mathrm{a}$ \\
\hline Brazlândia Branca & $86.5 b$ & $29.5 b$ & $116.0 \mathrm{~b}$ \\
\hline \multirow[t]{3}{*}{ Canadense } & $88.2 b$ & $23.1 b$ & $111.3 b$ \\
\hline & \multicolumn{3}{|c|}{ Brasilia-DF } \\
\hline & $\mathrm{CY}$ & NCY & TRY \\
\hline 9 & $50.4 \mathrm{~b}$ & $7.4 \mathrm{~b}$ & $57.8 b$ \\
\hline 75 & $36.0 \mathrm{~b}$ & $21.8 \mathrm{a}$ & $57.7 \mathrm{~b}$ \\
\hline Beauregard & $87.4 \mathrm{a}$ & $10.3 \mathrm{~b}$ & $97.7 \mathrm{a}$ \\
\hline \multirow[t]{3}{*}{ Brazlândia Branca } & $54.5 b$ & $3.9 c$ & $58.4 b$ \\
\hline & \multicolumn{3}{|c|}{ PAD-DF } \\
\hline & $\mathrm{CY}$ & $\mathrm{NCY}$ & TRY \\
\hline 9 & $32.4 \mathrm{a}$ & $7.5 \mathrm{~b}$ & $39.9 a$ \\
\hline 75 & $33.7 \mathrm{a}$ & $17.5 \mathrm{a}$ & $51.2 \mathrm{a}$ \\
\hline Beauregard & $34.8 \mathrm{a}$ & $8.0 \mathrm{~b}$ & $42.8 a$ \\
\hline Brazlândia Branca & $28.4 \mathrm{a}$ & $9.6 \mathrm{~b}$ & $37.9 \mathrm{a}$ \\
\hline \multirow[t]{3}{*}{ Canadense } & $40.4 \mathrm{a}$ & $8.4 b$ & $48.8 \mathrm{a}$ \\
\hline & \multicolumn{3}{|c|}{ Canoinhas-SC } \\
\hline & $\mathrm{CY}$ & $\mathrm{NCY}$ & TRY \\
\hline 9 & $19.4 \mathrm{a}$ & $5.9 a$ & $25.3 \mathrm{a}$ \\
\hline 75 & $22.2 \mathrm{a}$ & $5.6 \mathrm{a}$ & $27.8 \mathrm{a}$ \\
\hline \multirow[t]{3}{*}{ Beauregard } & $31.4 \mathrm{a}$ & $1.8 \mathrm{~b}$ & $33.2 \mathrm{a}$ \\
\hline & \multicolumn{3}{|c|}{ Altamira-PA } \\
\hline & $\mathrm{CY}$ & NCY & TRY \\
\hline 9 & $10.2 \mathrm{c}$ & $4.0 \mathrm{a}$ & $14.2 \mathrm{c}$ \\
\hline 75 & $19.8 \mathrm{~b}$ & $6.0 \mathrm{a}$ & $25.8 b$ \\
\hline Beauregard & $32.3 \mathrm{a}$ & $4.1 \mathrm{a}$ & $36.4 \mathrm{a}$ \\
\hline Brazlândia Branca & $14.3 \mathrm{c}$ & $3.4 \mathrm{a}$ & $17.8 \mathrm{c}$ \\
\hline Canadense & $5.1 d$ & $1.9 \mathrm{a}$ & $7.0 d$ \\
\hline
\end{tabular}

*Different letters within columns represent $p<0.05$ probability by Scott-Knott

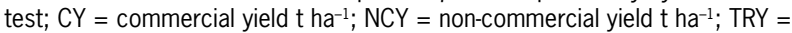
total root yield $\mathrm{t} \mathrm{ha}^{-1}$.

and clone 75 was the least (Figure 2 and Table 8). In the initial experimental evaluations, clone 75 was considered one of the most promising genotypes because of the high sugar concentration and the high DM content (data not show). However, field studies in Piacatú-SP, PAD-DF, and Altamira-PA demonstrated that this orange flesh sweet potato clone was very sensitive to climate variation presenting root cracks prior to harvesting. These roots are considered non-marketable resulting in a large number of noncommercial roots (Table 8).

The commercial yield of white flesh sweet potato clone 9 was very similar to the yield of white flesh commercial genotypes (Brazlândia Branca and Canadense) (Table 8). The five field trials in the second set of experiments showed no commercial advantage over clone 9 with both commercial genotypes. Based on this finding, it was decided that this clone would not be commercially released.
None of the experimental sweet potato clones tested in the set of experiments in this study, presented agronomic characteristics that justified their commercial launch. Cultivar Beauregard show low production of shoots, a limited forage source. However, this cultivar could be indicated for root production in all the regions evaluated, as it provides high yields of commercial roots. Since a large part of the Brazilian population prefers sweet potato genotypes with high DM content, different strategies are needed for this cultivar when it is not accepted in the boiled or baked forms (Santos et al., 2021). In addition, breeding programs in Brazil should focus on the development of high dry matter orange flesh sweet potatoes.

\section{Acknowledgments}

This work was supported by the Harvest Plus Program (grant number 2014H6332 - EMB) and kindly reviewed by Dr. Mary Shaw and Dr. Erich Yukio Tempel Nakasu.

\section{Authors' Contributions}

Conceptualization: Mello, A.F.S.; Carvalho, J.L.V.; Nuti, M.R. Data acquisition: Mello, A.F.S.; Nunes, M.U.C.; Celestino Filho, P.; Silva, W.B. Data analysis: Silva, G.O.; Moita, A.W. Design of methodology: Mello, A.F.S.; Nunes, M.U.C.; Silva, W.B. Writing and editing: Mello, A.F.S.; Silva, G.O.

\section{References}

Afolabi, M.; Bello, B.; Agbowuro, G.; Aremu, C.; Akoroda, M. 2019. Diallel analysis of sweet potato [Ipomoea batatas (L.) Lam] genotypes for combined beta carotene and dry matter content in southern Guinea Savanna, Nigeria. Journal of Agriculture and Ecology Research International 19: 1-9.

Afuape, S.O.; Okocha, P.I.; Njoku, D. 2011. Multivariate assessment of the agromorphological variability and yield components among sweetpotato (Ipomoea batatas (L.) Lam) landraces. African Journal of Plant Science 5: 123-132.

Andrade Junior, V.C.; Viana, D.J.S.; Fernandes, J.S.C.; Figueiredo, J.Á.; Nunes, U.R.; Neiva, I.P. 2009. Selection of sweet potato clones for the region Alto Vale do Jequitinhonha. Horticultura Brasileira 27: 389-393.

Cecílio Filho, A.B.; Nascimento, S.M.; Silva, A.S.; Vargas, P.F. 2016. Agronomic performance of sweet potato with different potassium fertilization rates. Horticultura Brasileira 34: 588592.

Dumbuya, G.; Sarkodie-Addo, J.; Daramy, M.; Jalloh, M. 2016. Growth and yield response of sweet potato to different tillage methods and phosphorus fertilizer rates in Ghana. Journal of Experimental Biology and Agricultural Sciences 4: 475-483.

Egbe, O.; Afuape, S.; Idoko, J. 2012. Performance of improved sweet potato (Ipomea batatas L.) varieties in Makurdi, southern Guinea Savanna of Nigeria. American Journal of Experimental Agriculture 2: 573-586. 
Instituto Brasileiro de Geografia e Estatística [IBGE]. 2021. Municipal Agricultural Production: Information on Temporary Crops = Produção Municipal Agrícola: Informações sobre Culturas Temporárias, IBGE, Rio de Janeiro, RJ, Brazil (in Portuguese).

Melo, R.A.C.; Silva, G.O.; Vendrame, L.P.; Pilon, L.; Guimarães, J.A.; Amaro, G.B. 2020. Evaluation of purple-fleshed sweetpotato genotypes for root yield, quality and pest resistance. Horticultura Brasileira 38: 439-444.

Ministério da Agricultura, Pecuária e Abastecimento [MAPA]. 2021. Registered sweet potato cultivars = Cultivares de batatadoce registradas. Available at: http://sistemas.agricultura.gov. $\mathrm{br} / \mathrm{snpc/cultivarweb/cultivares \_ registradas.php.} \mathrm{[Accessed} \mathrm{on}$ Feb 2, 2021] (in Portuguese).

Miranda, G.V.; Souza, L.V.D.; Guimarães, L.J.M.; Namorato, H.; Oliveira, L.R.; Soares, M.O. 2009. Multivariate analyses of genotype $\mathrm{x}$ environment interaction of popcorn. Pesquisa Agropecuária Brasileira 44: 45-50.

Miranda, J.E.C. 1989. Brazlândia roxa, brazlândia branca, brazlândia rosada e coquinho: new sweet potato cultivars. Horticultura Brasileira 7: 32-33 (in Portuguese, with abstract in English).

Nwosisi, C.; Nandwani, D.; Pokharel, B. 2017. Yield performance of organic sweetpotato varieties in various mulches. Horticulturae 3: 48

Rolston, L.; Clark, C.; Cannon, J.; Randle, W.; Riley, E.; Wlson, P.; Robbins, M. 1987. Beauregard sweet-potato. HortScience 22: 1338-1339.
Santos, F.N.; Duarte, L.N.; Samborski, T.; Mello, A.F.S.; Kringel, D.H.; Severo, J. 2021. Elaboration of food products with biofortified sweet potatoes: characterization and sensory acceptability. Revista Chilena de Nutrición 48: 59-66.

Santos, H.G.D.; Jacomine, P.K.T.; Anjos, L.H.C.D.; Oliveira, V.A.D.; Lumbreras, J.F.; Coelho, M.R.; Almeida, J.A.D.; Araujo Filho, J.C.D.; Oliveira, J.B.D.; Cunha, T.J.F. 2018. Brazilian Soil Classification System. Embrapa Soils, Rio de Janeiro, RJ, Brazil.

Schultheis, J.R.; Walters, S.A.; Adams, D.E.; Estes, E.A. 1999. In row plant spacing and date of harvest of 'Beauregard' sweetpotato affect yield and return on investment. HortScience 34: 1229-1233.

Vargas, P.F.; Engelking, E.W.; Almeida, L.C.F.; Ferreira, E.A.; Charlo, H.C.O. 2018. Genetic diversity among sweet potato crops cultivated by traditional farmers. Revista Caatinga 31 : 779-790.

Zobel, R.; Wright, M.; Gauch, H. 1988. Statistical Analysis of a Yield Trial. Agronomy Journal 80: 388-393.

Zunfu, L.; Weichen, H.; Lizhuo, L.; Lijuan, D.; Minyi, Y.; Cong, F.; Jie, W.; Ruoyi, J.; Mengjie, H.; Peng, C.; Huqing, Y.; Guoquan, L. 2020. Development of critical shoot and root $\mathrm{N}$ curves for diagnosing sweetpotato shoot and root N status. Field Crops Research 257: 107927. 